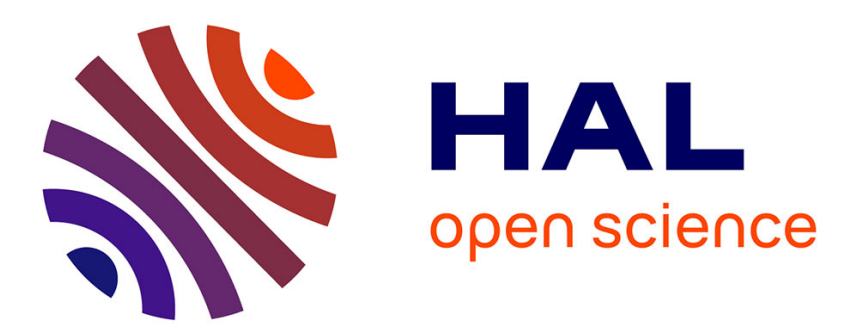

\title{
The Sunlight and the Hidden Paintings in the Church of San Lorenzo in Torino
}

\author{
Amelia Carolina Sparavigna, Lidia Dastrù
}

\section{To cite this version:}

Amelia Carolina Sparavigna, Lidia Dastrù. The Sunlight and the Hidden Paintings in the Church of San Lorenzo in Torino. 2017. hal-01649928

\section{HAL Id: hal-01649928 \\ https://hal.science/hal-01649928}

Preprint submitted on 28 Nov 2017

HAL is a multi-disciplinary open access archive for the deposit and dissemination of scientific research documents, whether they are published or not. The documents may come from teaching and research institutions in France or abroad, or from public or private research centers.
L'archive ouverte pluridisciplinaire HAL, est destinée au dépôt et à la diffusion de documents scientifiques de niveau recherche, publiés ou non, émanant des établissements d'enseignement et de recherche français ou étrangers, des laboratoires publics ou privés. 


\title{
The Sunlight and the Hidden Paintings in the Church of San Lorenzo in Torino
}

\author{
Amelia Carolina Sparavigna ${ }^{1}$ and Lidia Dastrù ${ }^{2}$ \\ ${ }^{1}$ Politecnico di Torino, Torino, Italy \\ ${ }^{2}$ Ricercatrice Indipendente, Torino, Italy
}

\begin{abstract}
The Real Chiesa di San Lorenzo is a church designed and built by Guarino Guarini. This church, adjacent to the Royal Palace in Piazza Castello, is one of the most beautiful churches in Torino. It possesses a remarkable cupola, made by a series of nested octagons. The lower part of the church has no windows. The natural light is coming from large windows above the base of the dome and other smaller openings in it. Besides the high altar, we find in the church two lateral altars and four radial chapels. In the chapels, Guarino Guarini has hidden some paintings inside their double vaults. These paintings are visible only when the sunlight is passing through a specific oculus in the front of the chapel. This happens when the sun has the right azimuth and altitude. Actually, the architect had used his knowledge of astronomy and geometrical optics to create this effect. Here we discuss it and the required position of the sun, using software for evaluating solar altitude and azimuth.
\end{abstract}

Keywords: Architecture, Archaeostronomy, Photographer's Ephemeris Software.

In several publications, we find discussed the astronomical orientations of churches and cathedrals and the possible alignments of them along the directions of sunrise [1-19]. However, religious buildings can be linked to the sunlight by other optical effects, and these effects that can be evidenced by some research work, such as in [20,21]. Here, we consider an example that we can find in a church designed by Guarino Guarini (1624-1683). This church, adjacent to the Royal Palace in Piazza Castello, is one of the most beautiful churches in Torino. It is the Real Chiesa di San Lorenzo.

Guarino Guarini started to build the church in 1668. The building was finished in 1687, after the death of the architect. In San Lorenzo, Guarini used his knowledges of astronomy and of the apparent motion of the sun, to enhance the role of the light in the building. In fact, this architect, who was a great innovator of the Baroque style, had a special attention to optical effects and to their related symbolisms [22]. Let us also note that, besides a treatise on architecture that was published posthumously, Guarini wrote some works on natural philosophy, geometry and astronomy.

For what concerns the geometry of its layout, the church of San Lorenzo is a square at the basement, which becomes an octagon inside the church at the level of the entablatures. Then the design becomes a Greek cross at the level of the pendentives of the cupola [23]. The base of the cupola is circular in plan, but the cupola itself is a series of nested octagons. The dome "is supported by eight ribs forming a lattice similar to those found in mosques and Romanesque churches in Spain" [23]. From the outside, the church and the cupola appear as in the Figure 1, whereas, on the inside, the cupola is as shown in the Figure 2. Actually, in the layout of this church, Guarini used a sequence of square, octagon and circle to represent the world and the heavens [24].

The lower part of the church has no windows. We find in it the high altar, two lateral altars and four radial chapels. The high altar, which is separated from the nave by an archway, receives natural light from a hidden smaller dome. Above the lower part of the church, some large windows exist (see again Figures 1 and 2). As explained in [25], Guarini designed the plan of the lower part of the church (the octagon) as a metaphor of our earthly life. However, by means of its dome, the architect is remarking that God is offering us an opportunity of salvation: when we raise our eyes to see the light of the cupola, we raise our thoughts toward His Divine Light.

Let us continue discussing the chapels. The radial chapels have an oculus which is placed in the front of them (see Figure 3). The chapels have a peculiarity. In their vault we can see a six-pointed 
star with another oculus at the center, a hole which seems totally useless (see Figure 4). But it is not so. As told in [26], there is a little secret in these chapels. Inside the vaults, which are double vaults, there are some hidden paintings visible only at certain conditions. The paintings are visible when the hole in front of the chapel is illuminated by the sunlight. This happens at given moments of the year and only under good weather conditions. In fact, besides being a genius of architecture, Guarino Guarini was also an astronomer, and in San Lorenzo he proved his geniality in linking the church to the apparent motion of the sun in the sky.

To continue our discussion it is necessary to consider the plan of the church (Figure 5), in particular of the chapels, and give the name of them (Figure 6). Let us consider the oculus in the center of the six-pointed star of the Chapel of the Immacolata [27]. It is designed to remain in the dark and cannot be seen inside. But, about noon of a few days around the Spring and Autumn Equinoxes, the sunlight comes from one of the large windows and hits the oculus in front of the chapel. The secret fresco inside the double vault, that of God the Father blessing the world in His hand, becomes visible. Moreover, the appearance of another fresco occurs in the opposite chapel. "The reflection of the light also makes visible another fresco, diametrically opposite, above the altar of the Souls in Purgatory, with Jesus Christ in the act of Blessing" [27].

The same reference is telling that "In the early morning during the same periods of the year, the same effect can be seen above the other two lateral altars of the Nativity and the Crucifix" [27]. Actually, the phenomenon for these two chapels does not happen as described by [27], but in the afternoon of a few days in May and July. Therefore, let us study the two cases and given some data and dates for the phenomenon. We start from a detailed exam of the phenomenon for the Chapel of the Immacolata. First, what is the window through which the sunlight is passing to hit the oculus in the front of this chapel? To answer the question we can use a Guarini's drawing of San Lorenzo, that we can find in his book [28], here given in the Figure 7. From the drawing, we can see that the light, which hits the oculus of the chapel, is coming from one of the large windows in the cupola, and this can happen when the sun has an altitude of about $43^{\circ}$.

Let us use software "The Photographer's Ephemeris" to see azimuth and altitude of the sun, on 20 March 2017, the Spring Equinox. This software gives azimuths of sun and moon on satellite images. The altitudes are given in a graph as a function of time. In the image (Figure 8), we see the directions of sunrise (thick yellow line) and sunset (orange thick line). The blue lines are corresponding to moonrise and moonset. The thin yellow line, which gives the direction of the sun at 11:38, is passing through one of the large windows. The pivot is coincident to the position of the oculus in the front of the chapel of Immacolata. It means that, if the altitude of the sun is close to the angle given in the Figure 7, the sun beam can reach the oculus and illuminate the hidden vault of the chapel. In the lower part of the image in the Figure 8, software is giving us the altitude of the sun. It is of about $43^{\circ}$, at 11:38. In this manner, we have analysed the phenomenon described in [27], and, by means of the software Photographer's Ephemeris, determined date, time, and required azimuth and altitude of the sun.

To observe the phenomenon in the chapel of the Crucifix, we need to be in the same condition. That is, the oculus in the front of the chapel needs being reached by the sunlight passing through the opposite large window. And we need an altitude of the sun of $43^{\circ}$. Let us use again The Photographer's Ephemeris. After some simulations, we found the proper conditions on 12 May 2017 (see Figure 9). The phenomenon is possible at 16:30, therefore in the afternoon. We are in the same condition in the afternoon of July 25.

We are planning to visit the church in different periods of the year to evidence the above-mentioned phenomena, linked to the hidden paintings in the chapels, and, possibly, to find other effects of the sunlight that Guarino Guarini had eventually hidden in his architecture.

\section{References}

[1] Heilbron, J. L. (2009). The sun in the church: cathedrals as solar observatories. Harvard University Press.

[2] Abril, J. M. (2017). Evidence of Churches Aligned to the Sun on the Patron Saint's Day in 
Southern Spain after the Twelfth Century, J. Skyscape Archaeology, 3(1).

[3] Liritzis, I., \& Vassiliou, H. (2007). Does sunrise day correlate with eastern orientation of byzantine churches on significant solar dates and saint's days? A preliminary study. Byzantinische Zeitschrift, 99(2), 523-534.

[4] Hinton, I. (2006). Church alignment and patronal saint's days. The Antiquaries Journal, 86, 206226.

[5] Caval, S. (2009, August). Astronomical orientations of Sacred Architecture during the Medieval period in Slovenia. In Cosmology Across Cultures (Vol. 409, p. 209).

[6] Ali, J. R., \& Cunich, P. (2001). The orientation of churches: some new evidence. The Antiquaries Journal, 81, 155-193.

[7] Ali, J. R., \& Cunich, P. (2005). The Church East and West: Orienting the Queen Anne Churches, 1711-34. Journal of the Society of Architectural Historians, 64(1), 56-73.

[8] Hoare, P. G., \& Sweet, C. S. (2000). The orientation of early medieval churches in England. Journal of Historical Geography, 26(2), 162-173.

[9] Hinton, I. D. (2010). Aspects of the alignment and location of medieval rural churches (Doctoral dissertation, University of East Anglia).

[10] Sassin Allen, A. (2016). Church Orientation in the Landscape: a Perspective from Medieval Wales. Archaeological Journal, 173(1), 154-187.

[11] McCluskey, S. C. (2015). Orientation of Christian Churches. In Handbook of Archaeoastronomy and Ethnoastronomy (pp. 1703-1710). Springer New York.

[12] Hutton, R. (1996). The stations of the sun: a history of the ritual year in Britain. Oxford University Press, USA.

[13] Dallas, T. G. (2015). On the Orientation of Byzantine Churches in Thessalonike. Mediterranean Archaeology and Archaeometry, 15(3), 213-224.

[14] Frincu, M., \& Giurginca, I. (2017). Astronomical Alignments of Paleo-Christian Basilicas in Romania. Sociology and Anthropology 5(5), 412-419.

[15] Gangui, A. (2016). Archaeoastronomy and the orientation of old churches. arXiv preprint arXiv:1604.00260.

[16] Spinazzè, E. (2016). The alignment of medieval churches in northern-central Italy and in the Alps and the path of light inside the chrch on the patron saint's day. Mediterranean Archaeology \& Archaeometry, 16(4), 455-463.

[17] Gangui, A., Garcia, A., Betancort, M. A. P., \& Belmonte, J. A. (2016). The orientation as a signature of cultural identity: The historic churches of Lanzarote. arXiv preprint arXiv:1604.03863.

[18] Sparavigna, A. C. (2012). Ad Orientem: the Orientation of Gothic Cathedrals of France. arXiv preprint arXiv:1209.2338.

[19] Sparavigna, A. C. (2014). The Solar Orientation of the Gothic Cathedrals of France. International Journal of Sciences, 3(04), 6-11.

[20] Benfer, R. A. (2016). Light beams and architecture marked celestial events in colonial churches and missions in New Spain and Peru: New evidence from Morelia. Mediterranean Archaeology and Archaeometry, 16(4), 481-485.

[21] Sparavigna, A. C. (2015). Light and Shadows in Bernini's Oval of Saint Peter's Square (November 8, 2015). Philica, Article n.540. Available at SSRN: https://ssrn.com/abstract=2742281

[22] Badillo, N. (2012). Ocularium Lucis: Light and Optical Theory in Guarino Guarini's Church of San Lorenzo. The University of Arizona.

[23] Vv. Aa. (2017). Wikipedia. https://en.wikipedia.org/wiki/Church_of_San_Lorenzo,_Turin

[24] Mandelli, E., Lavoratti, G. (2010). Disegnare il tempo e l'armonia: il disegno di architettura osservatorio nell'universo, Volume 1, Alinea Editrice.

[25] Vv. Aa. (2017). http://www.atourinturin.com/2016/01/diavoli-famosi-e-affreschi-nascosti.html

[26] Vv. Aa. (2017). http://www.guidatorino.com/i-dipinti-segreti-della-chiesa-di-san-lorenzo-atorino/

[27] Vv. Aa. (2017). http://eng.sanlorenzo.torino.it/home/chiesa-reale/cappella-dell-immacolata

[28] Guarino Guarini (1737). Architettura civile. https://archive.org/details/ArchitetturaCivile 

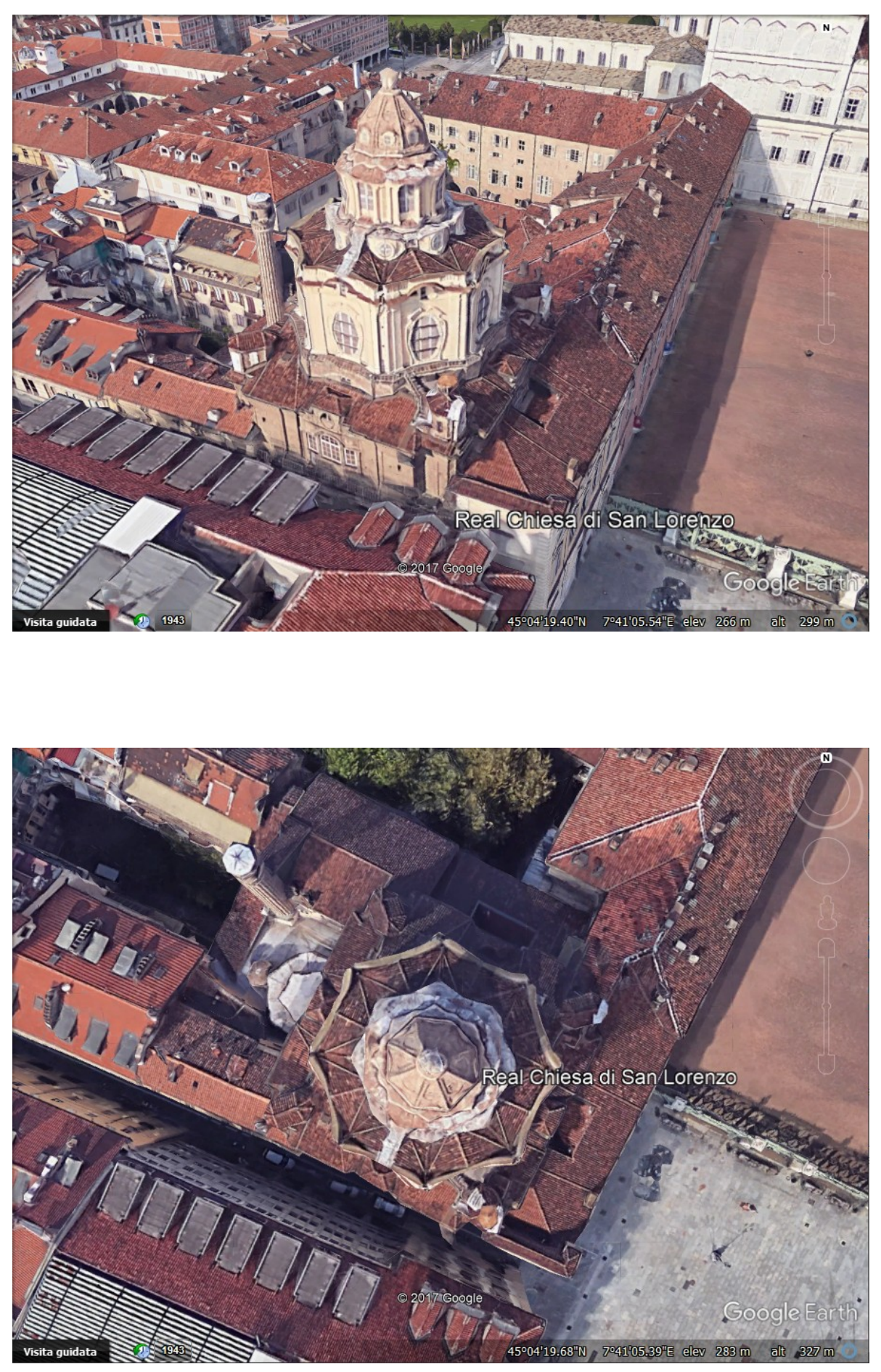

Figure 1: Guarino Guarini's San Lorenzo in the images from Google Earth. 


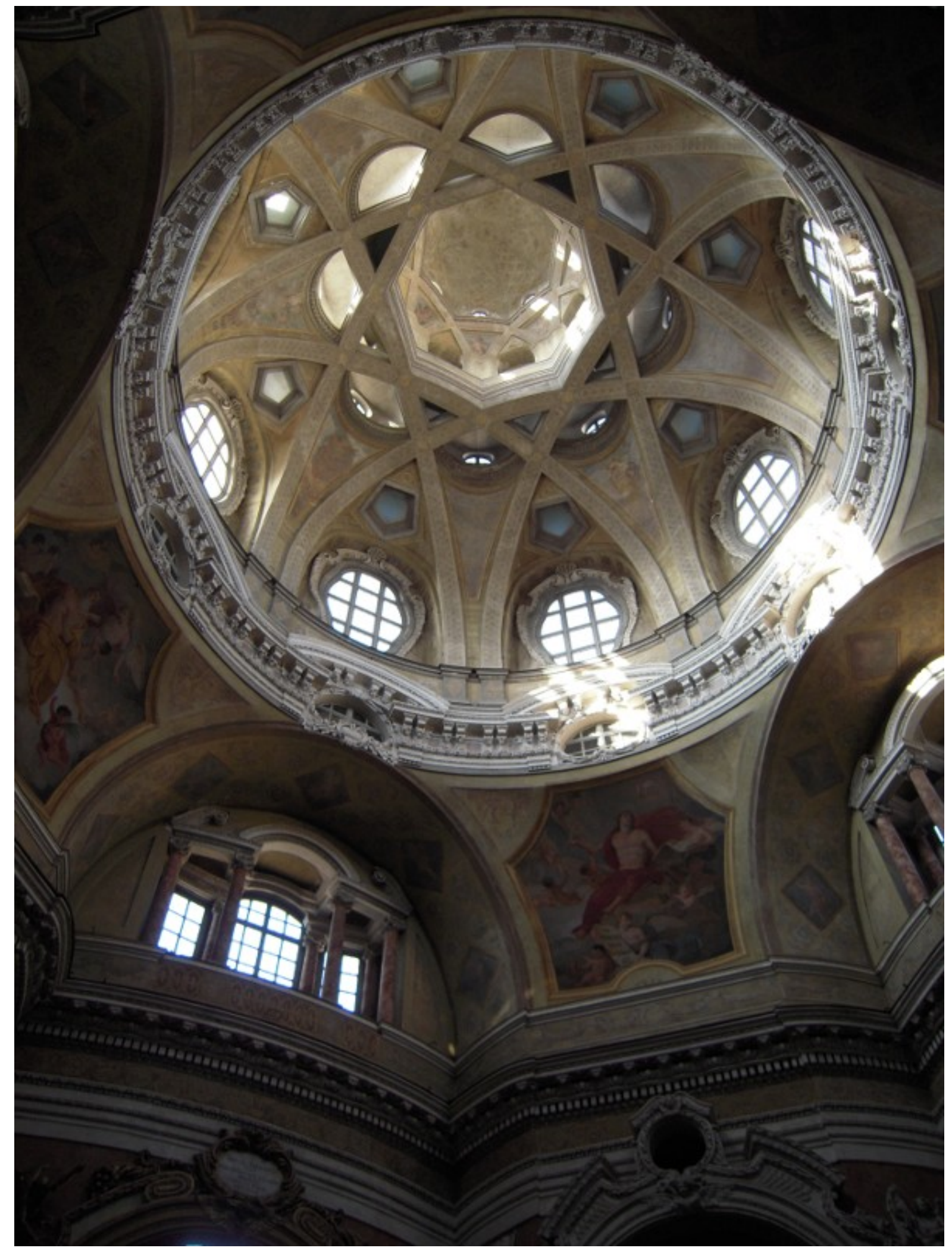

Figure 2: The cupola of San Lorenzo. 


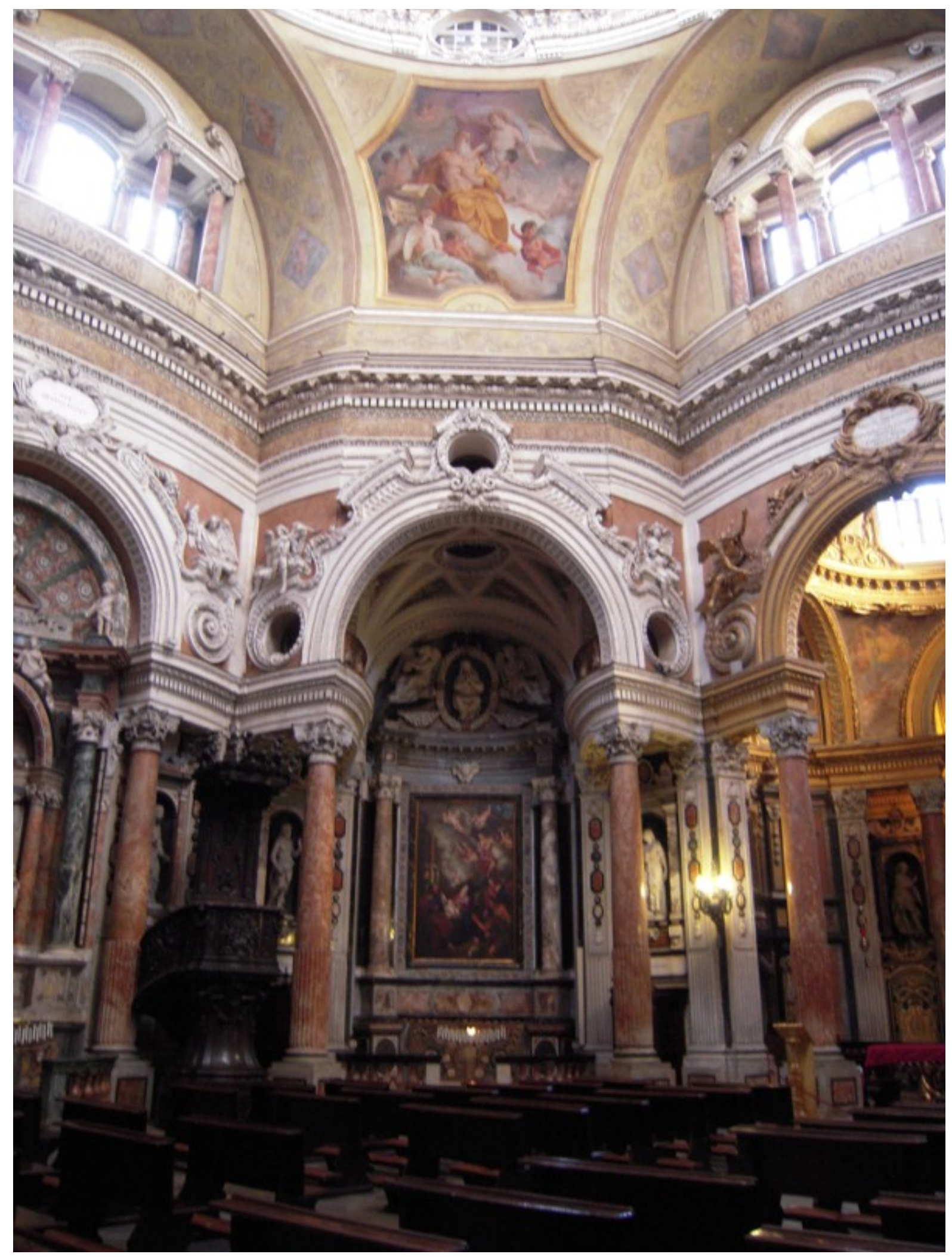

Figure 3. One of the radial chapels in San Lorenzo. Note the oculus in the front of the chapel. 


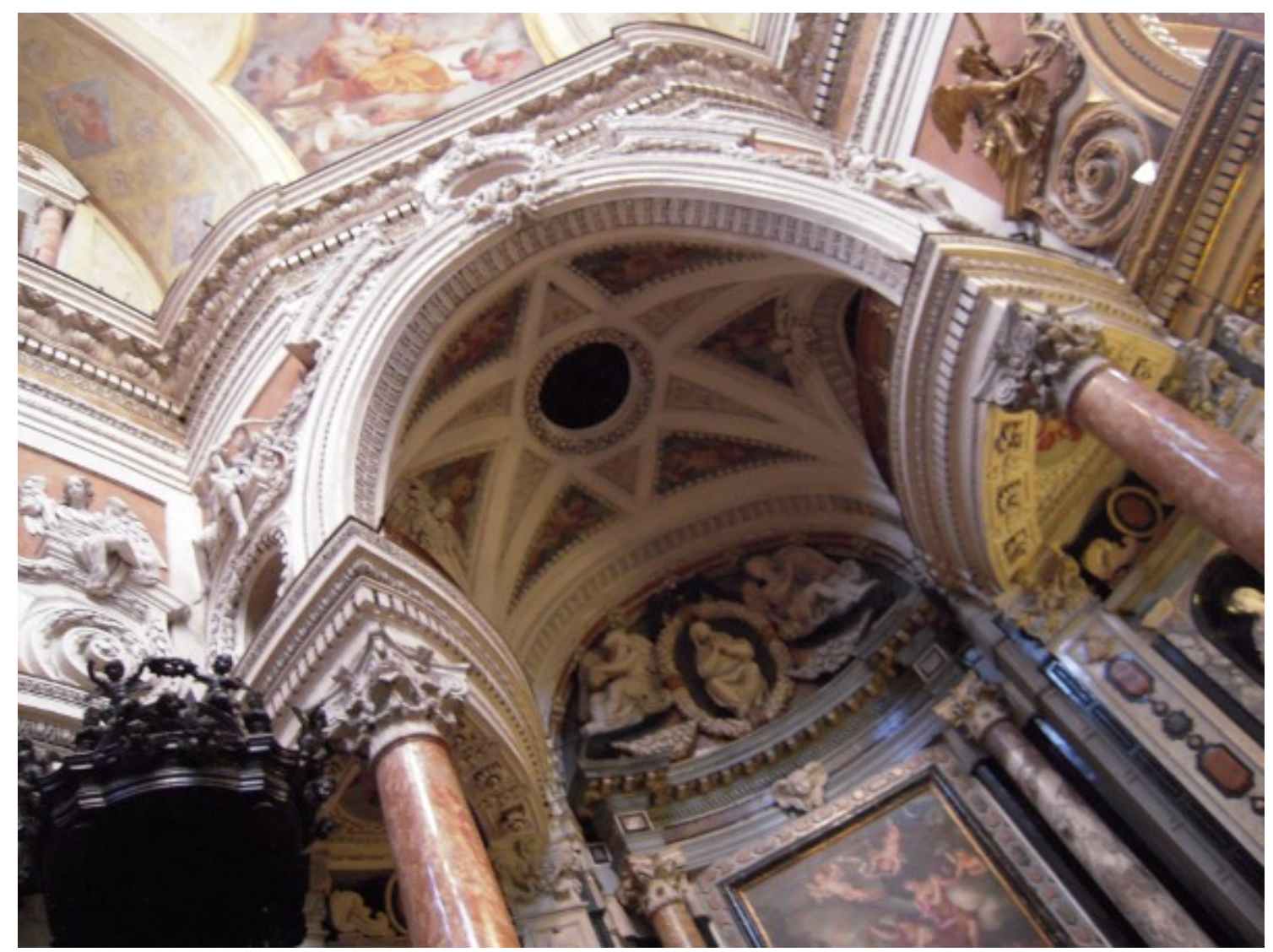

Figure 4: Detail of the vault of the chapel shown in the Figure 3. Let us remark that the chapel has a double vault. We can see a six-pointed star depicted on it with an oculus at the center, a hole which seems totally useless. As told in [26], there is a little secret here. Inside the double vault there is a hidden painting, visible only when the hole in front of the chapel is illuminated by the sun beams. This happens at specific moments of the year and only under good weather conditions. 


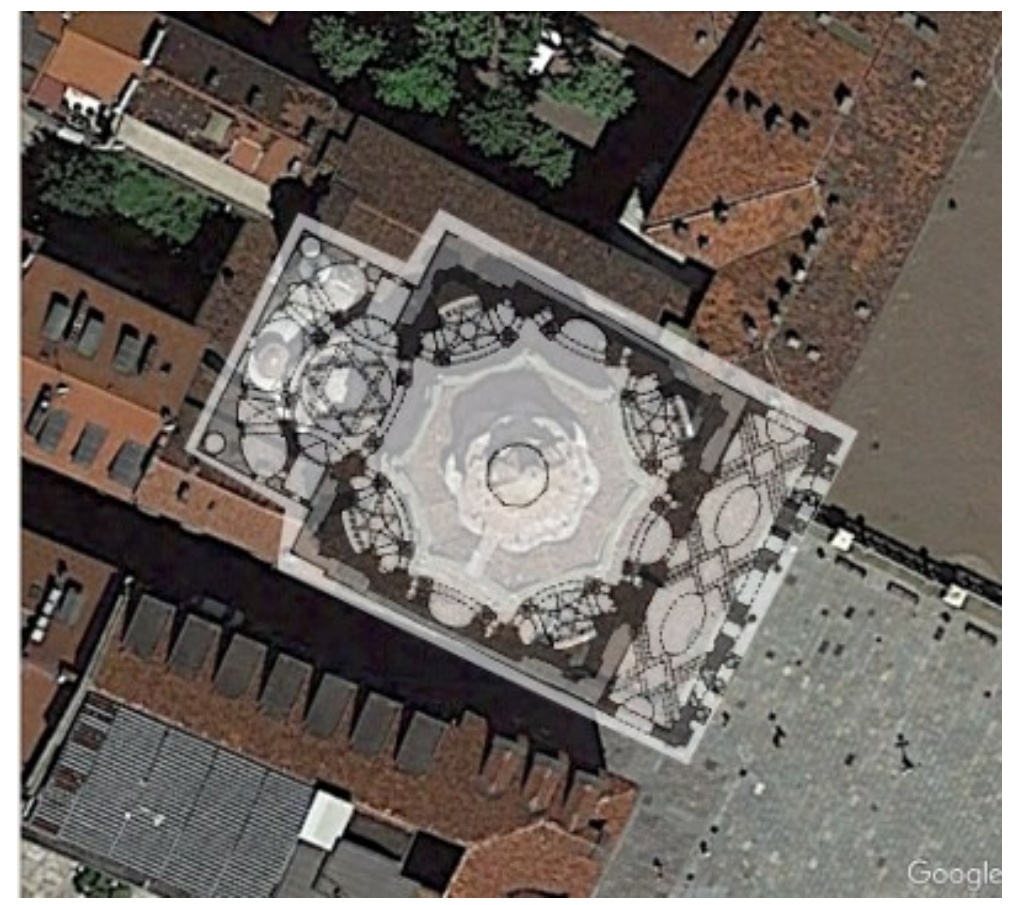

Figure 5: Plan of the church given on the satellite image.

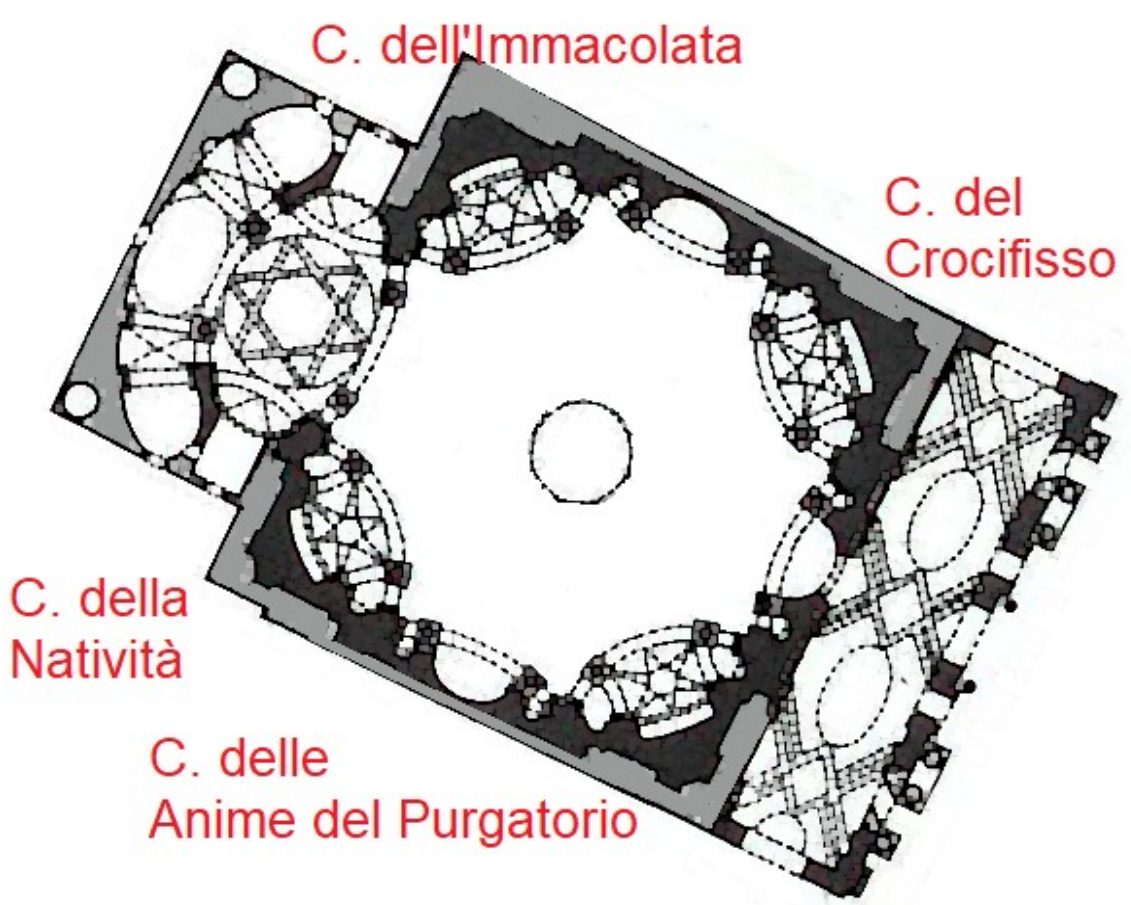

Figure 6: The radial chapels. 


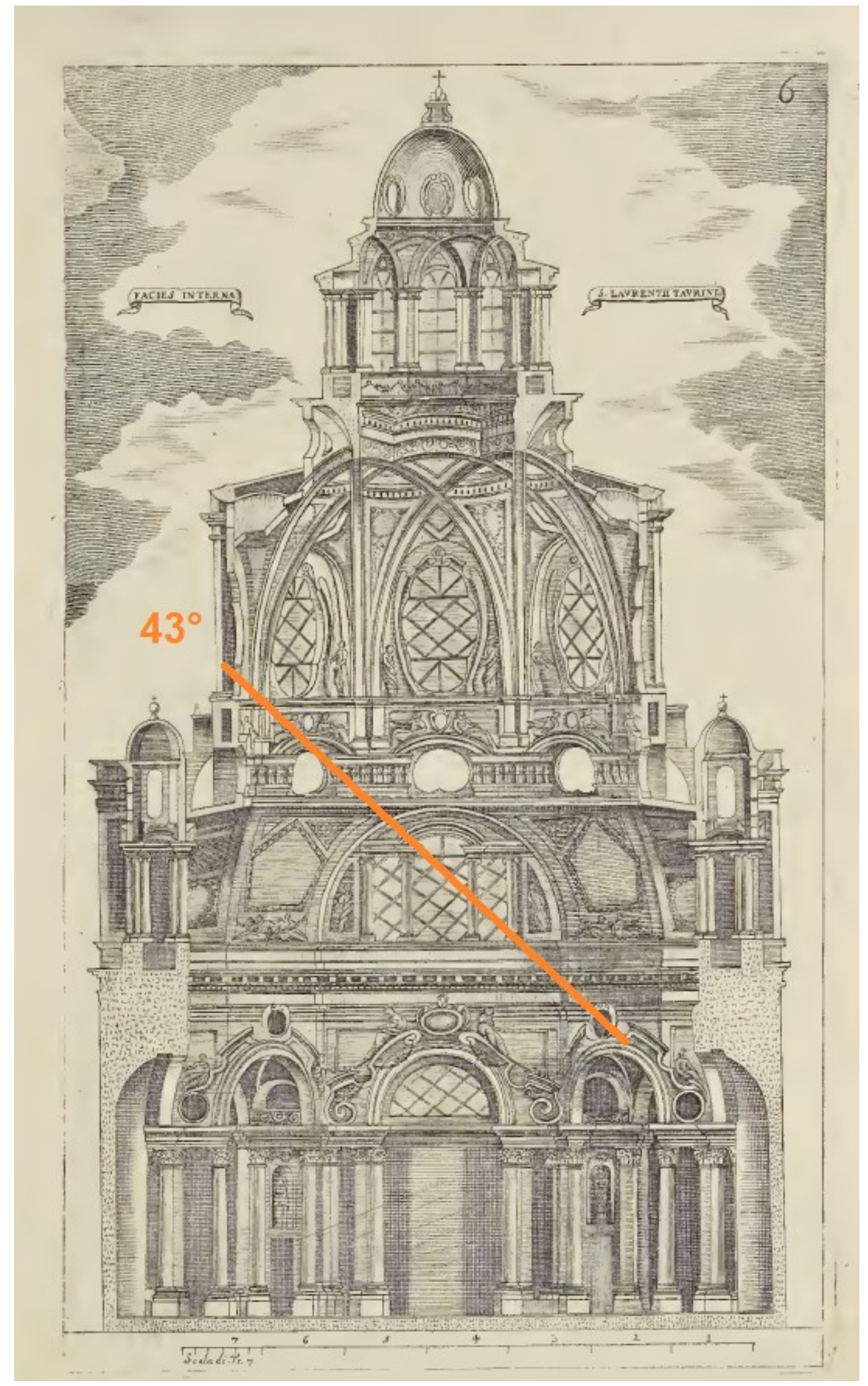

Figure 7: To have the sunlight hitting the oculus of the chapel, the altitude of the sun must be of about $43^{\circ}$. 


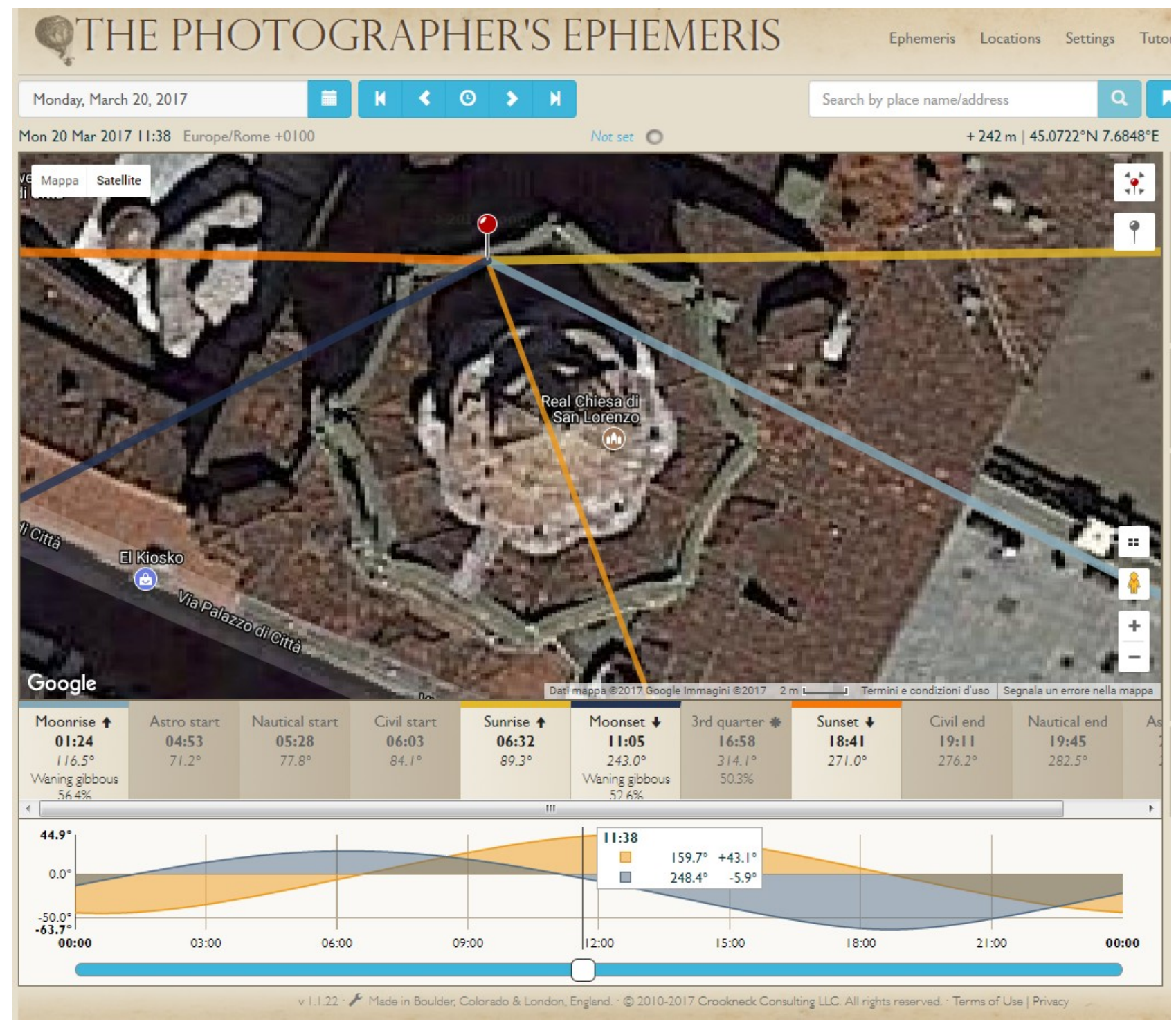

Figure 8: To investigate the phenomenon in the chapel of the Immacolata, let us use software "The Photographer's Ephemeris". It allows us to see the direction of the sun on 20 March 2017, the Spring Equinox. In the image we see the directions of sunrise (thick yellow line) and sunset (orange thick line). The blue lines are corresponding to moonrise and moonset. The thin yellow line, which gives the direction of the sun at 11:38, is passing through one of the large windows. The pivot is coincident to the position of the oculus in the front of the chapel of Immacolata. It means that, if the altitude of the sun is close to the angle given in the Figure 7, the sun beam can reach the oculus and illuminate the hidden vault of the chapel. In the lower part of the image, software is giving us the altitude of the sun. It is of about $43^{\circ}$. So the phenomenon is possible. Of course, the same is true for the Autumn Equinox. 


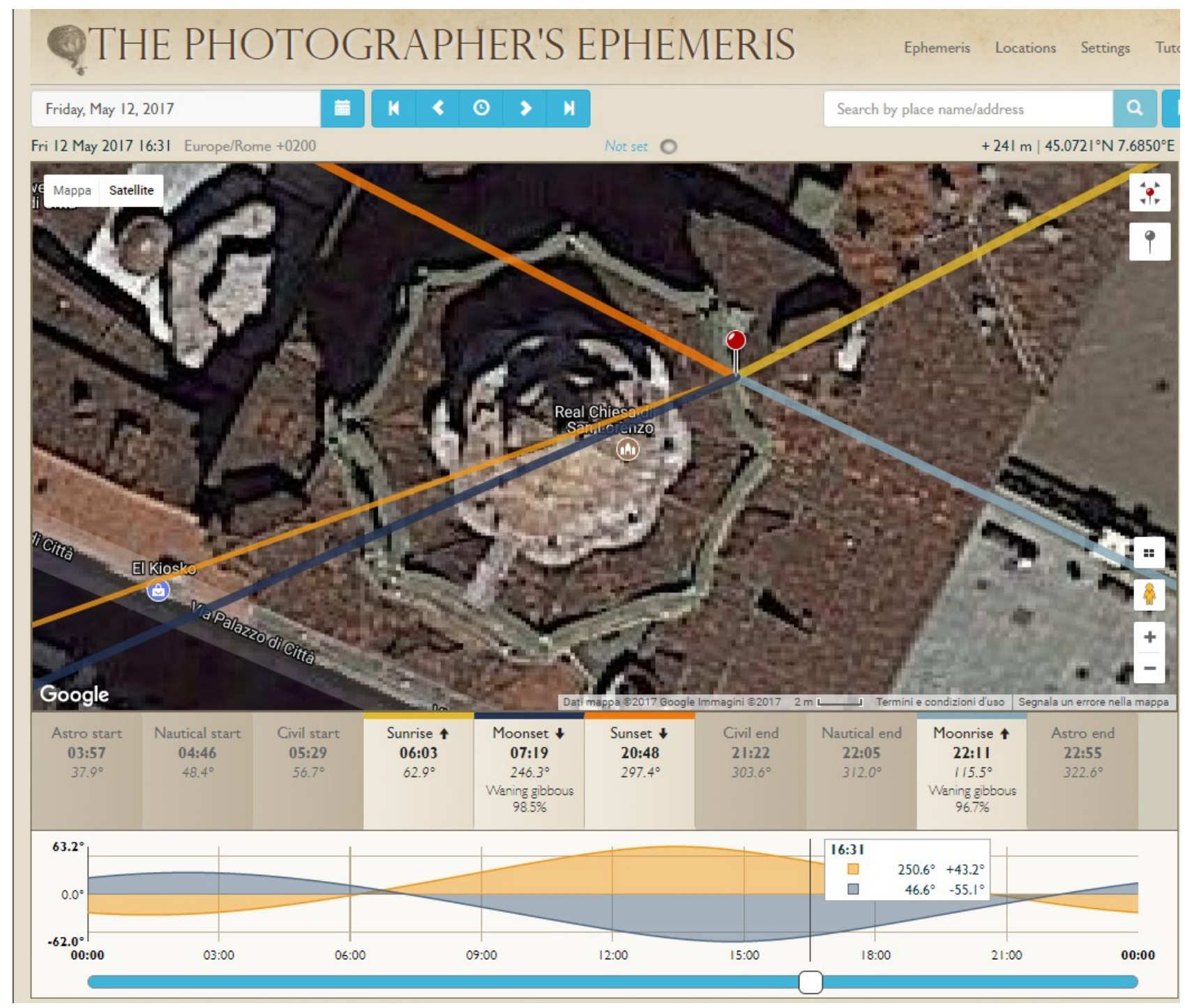

Figure 9: To investigate the phenomenon in the chapel of the Crucifix, let us use again software "The Photographer's Ephemeris". After some simulations, we found the proper condition on 12 May 2017. The pivot is coincident to the position of the oculus in the front of the chapel of the Crucifix. If the altitude of the sun is close to the angle of $43^{\circ}$, given in the Figure 7 , the sun beams can reach the oculus and illuminate the hidden vault of the chapel. In the lower part of the image, software is giving us the altitude of the sun. It is of about $43^{\circ}$. So the phenomenon is possible at 16:30, therefore in the afternoon. We are in the same condition on July 25. 